\title{
The in Vitro Cytopathology of a Porcine and the Simian (SA-11) Strains of Rotavirus
}

\author{
Juliana Galera Castilho/ ${ }^{++}$, Maria Valéria Jacobucci Botelho, Flávio Lauretti, \\ Noemi Taniwaki*, Rosa Elisa Carvalho Linhares, Carlos Nozawa/ ${ }^{+}$
}

\author{
Departamento de Microbiologia, CCB, Universidade Estadual de Londrina, Caixa Postal 6001, 86051-970 Londrina, PR, Brasil \\ *Seção de Microscopia Eletrônica, Instituto Adolfo Lutz, São Paulo, SP, Brasil
}

Rotaviruses have been implicated as the major causal agents of acute diarrhoea in mammals and fowls. Experimental rotavirus infection have been associated to a series of sub-cellular pathologic alterations leading to cell lysis which may represent key functions in the pathogenesis of the diarrhoeic disease. The current work describes the cytopathic changes in cultured MA-104 cells infected by a simian (SA-11) and a porcine (1154) rotavirus strains. Trypan blue exclusion staining showed increased cell permeability after infection by both strains, as demonstrated by cell viability. This effect was confirmed by the leakage of infected cells evaluated by chromium release. Nuclear fragmentation was observed by acridine orange and Wright staining but specific DNA cleavage was not detected. Ultrastructural changes, such as chromatin condensation, cytoplasm vacuolisation, and loss of intercellular contact were shown in infected cells for both strains. In situ terminal deoxynucleotidyl transferase (Tunel) assay did not show positive result. In conclusion, we demonstrated that both strains of rotavirus induced necrosis as the major degenerative effect.

Key words: rotavirus - cytopathology - necrosis - apoptosis - cell culture

Rotaviruses are the main cause of acute diarrhoea in newborn and young mammals and some avian species (Kapikian \& Chanock 1996). The genus rotavirus, within the family Reoviridae, consists of viruses that present eleven segments of double-stranded RNA and $70 \mathrm{~nm}$ in diameter (Shaw et al. 1995). The virions are icosaedric and non-enveloped with a concentric triple-layered doubleshelled capsid. The outer layer is made of VP4 and VP7 proteins, the intermediate layer constituted of VP6 and the inner layer represented by VP2. VP1-VP3, and the genome form the virion core (Patton 1995).

The viruses infect villous enterocytes of the small intestine (Blacklow \& Greenberg 1991) causing cell lysis and sloughing of the epithelium cells. The mechanism of rotavirus-induced diarrhoea is multifactorial and among the proposed causes is the secretory effect attributed to nonstructural virus protein (NSP4) and/or to the stimulation of enteric nervous system (Lundgren \& Svensson 2001). Although many pathways of rotavirus morphogenesis and several cytopathic effect features are established, virus-induced cell death remains uncertain. It was shown that experimental rotavirus infection promoted a progressive change in membrane permeability to cations

Financial support: Capes, $\mathrm{CNP} q$ and CPG/UEL

${ }^{+}$Corresponding author. Fax: +55-43-3371.4207. E-mail: cnoz@uel.br

${ }^{++}$JGC was recipient of Capes scholarship, and this work is part of her MSc manuscript.

Received 13 February 2004

Accepted 12 April 2004
(Michelangeli et al. 1995). Additionally, Perez et al. (1998) also showed cell rounding and loss of membrane integrity demonstrated by the increase of membrane permeability to macromolecules and release of cellular contents. All these features point at necrosis as the outcome of rotavirus infection. However, changes such as peripheral condensation of the chromatin and fragmentation of the nucleus were found as suggestive of apoptosis induced by the virus in HT29 cell culture (Superti et al. 1996).

Necrosis is a non-specific form of cell death following injury from an external agent. It is characterized by cell swelling, loss of plasma membrane integrity, and leakage of the cell contents after rupture of the cell (Majno \& Joris 1995).

Apoptosis, on the other hand, is a process of physiological cellular death in that cells are submitted to death in response to a variety of stimuli (Teodoro \& Branton 1997). Morphologically it is characterized by the reduction of cellular volume, loss of intercellular contact, condensation of the chromatin at the nuclear periphery, vacuolisation of the cytoplasm, cell membrane "blebbing", and formation of apoptotic bodies. In some cases activation of endogenous endonucleases occurs and results in cellular DNA cleavage in oligonucleosomal fragments of multiples of 180 to $200 \mathrm{pb}$, differently to the random DNA fragmentation observed in necrosis (Wyllie et al. 1984).

It has been shown that apoptosis induced by several virus infections contribute directly to the cytopathology and pathogenesis of those infections (Alonso et al. 1998, Oura et al. 1998). Evidences also show that many viruses encode specific proteins that arrest apoptosis (Tolskaya et al. 1995, Teodoro \& Branton 1997, Derfuss et al. 1998).

The current work was proposed to evaluate the outcome of a porcine and simian rotavirus infection underlying their in vitro cytophatology. 


\section{MATERIALS AND METHODS}

Virus and cell culture - Simian (SA-11) and porcine (strain 1154) (Ramos et al. 2000) strains of rotavirus were grown in MA-104 cell cultures (monkey kidney cells) maintained in Dulbecco's Modified Eagle Medium free of foetal bovine serum (FBS), with antibiotics, and $10 \mu \mathrm{g} / \mathrm{ml}$ of crystalline trypsin used throughout, unless otherwise indicated. Virus inocula were previously treated with $30 \mu \mathrm{g} /$ $\mathrm{ml}$ of trypsin for $50 \mathrm{~min}$ at $37^{\circ} \mathrm{C}$, and for the experiments cell cultures grown in Leighton tubes or $150 \mathrm{ml}$-tissue culture bottles (at an initial cell density of $10^{6}$ cells $/ \mathrm{ml}$ ) were infected at a multiplicity of infection (m.o.i.) of approximately 1 throughout, unless otherwise stated.

Trypan blue exclusion staining (TB) - Coverslips with virus-infected cell cultures, as well as uninfected cultures, were harvested at $0,2,4,6,8,10$, and $12 \mathrm{~h}$ p.i. and stained with $1 \% \mathrm{~TB}$. Results are represented as the percentage of viable cell, calculated by $\mathrm{X}=100-(\mathrm{A} / \mathrm{B} \times 100)$, where $\mathrm{A}$ is the number of infected (death) cells and $B$ is the number of live (control) cells. The number of cells (A and B) is the average of three independent counts.

Chromium $\left({ }^{51} \mathrm{Cr}\right)$ release assay $(\mathrm{CR})$ - Briefly, $48 \mathrm{~h}$ confluent cell cultures were dispersed with $0.02 \%$ EDTA, centrifuged, and the pellet was resuspended in $5 \mathrm{ml}$ of culture medium containing $100 \mu \mathrm{Ci}$ of $\mathrm{Na}_{2}\left[{ }^{51} \mathrm{Cr}\right] \mathrm{O}_{4}(3.6 \mu \mathrm{g}$ $\mathrm{Cr} / \mathrm{ml}$ ) (Amersham Pharm. Byotech, São Paulo, Brazil) and incubated for $45 \mathrm{~min}$ at $37^{\circ} \mathrm{C}$. Cell suspension was washed twice with warm medium and the resultant pellet resuspended in $5 \mathrm{ml}$ medium, and split into two equal volumes. The cells were infected with virus, previously treated with $30 \mu \mathrm{g} / \mathrm{ml}$ of trypsin. After adsorption and cell pelleting, fluid medium containing viral inocula was discarded, cells resuspended in fresh culture medium containing 5\% FBS and $10 \mu \mathrm{g} / \mathrm{ml}$ trypsin, and $1 \mathrm{ml}$-aliquot of cell suspension placed in culture tubes. Mock-infected cultures were prepared similarly. At time intervals of 0, 2, 4, 6, 8, 10, and 12 $\mathrm{h}$ p.i., cultures were centrifuged and the supernatant submitted to radioactivity counts in gamma counter (Polos \& Gallaher 1981). The percentage of chromium release was calculated by $\mathrm{X}=\mathrm{C} / \mathrm{D} \times 100$, where $\mathrm{C}$ is cpm (count per minute) in the supernatant of infected cells and $\mathrm{D}$ is cpm in the supernatant of non-infected cells. Counts of $\mathrm{C}$ and $\mathrm{D}$ are the average of three independent counts.

Acridine orange staining (AO) - Briefly, cell cultures grown in coverslips and infected with virus were harvested at $24 \mathrm{~h}$ and $48 \mathrm{~h}$ p.i., and fixed with Carnoy's fixative for $5 \mathrm{~min}$ followed by hydration with decreasing concentrations of ethanol. Cells were washed in McIlvaine's buffer stained with $4.3 \mu \mathrm{M}$ AO for $5 \mathrm{~min}$, and observed under UV light (Guimarães \& Nozawa 1990).

Wright staining (WS) - Infected cultures were harvested at $24 \mathrm{~h}$ and $48 \mathrm{~h}$ p.i., washed with PBS, fixed with methanol for $1 \mathrm{~h}$, and overlaid with $0.3 \%$ Wright stain for $4 \mathrm{~min}$. Cultures were washed with phosphate buffer, $\mathrm{pH}$ 6.5 , mounted in slides, and observed.

Transmission electron microscopy - Infected cells were scrapped off from the tissue culture bottles at $12 \mathrm{~h}$ and 24 $\mathrm{h}$ p.i., washed by centrifugation with PBS, and fixed with $2.5 \%$ glutaraldehyde in $0.1 \mathrm{M}$ sodium cacodylate/ $0.2 \mathrm{M}$ sucrose buffer, $\mathrm{pH}$ 7.2. One percent osmium tetroxide post- fixation was followed by $1 \%$ uranyl acetate treatment. Dehydration was done with acetone followed by embedding in epon. Ultra-thin sections were stained with lead citrate and uranyl acetate (Uehara et al. 1992).

DNA fragmentation - Infected cells harvested at time intervals of $8,24,48$, and $96 \mathrm{~h}$ p.i. were treated with $500 \mu \mathrm{l}$ of lysis buffer (10 mM Tris-HCl; $10 \mathrm{mM} \mathrm{EDTA;} 0.5 \%$ SDS, $\mathrm{pH} 8.0$ ) at $56^{\circ} \mathrm{C}$ for $2 \mathrm{~h}$ and extracted with phenol/chloroform. Extracted DNA was precipitated overnight with $5 \mathrm{M}$ $\mathrm{NaCl}$ and isopropanol at $-20^{\circ} \mathrm{C}$, resuspended in $30 \mu \mathrm{l}$ TrisEDTA buffer (10 mM Tris-HCl; 1 mM EDTA, pH 8.0) and submitted to electrophoresis either in 1.5\% agarose (AGE) or 7\% polyacrylamide (PAGE) gels (McDonell et al. 1977, Herring et al. 1982).

In situ terminal deoxytransferase-mediated dUTP nick end-labelling (Tunel) - Twenty-four and $48 \mathrm{~h}$ p.i. cultures were treated with $2 \mu \mathrm{g} / \mathrm{ml}$ of proteinase $\mathrm{K}$ followed by $1 \mathrm{~h}$ incubation at $37^{\circ} \mathrm{C}$ with hybridization solution [100 mM sodium cacodilate, $\mathrm{pH} 6,5 ; 2 \mathrm{mM}$ cobalt chloride; $50 \mu \mathrm{g} / \mathrm{ml}$ bovine serum albumin; $30 \mathrm{U}$ terminal deoxynucleotidyl transferase (Tdt); $20 \mu \mathrm{m} 5$-BrdU; $4 \mu \mathrm{M}$ dGTP, dCTP, and dATP; $30 \mathrm{mM}$ Tris-HCl]. Cells were washed with $50 \%$ formamide followed by three washings with citrate-saline $(0.3 \mathrm{M} \mathrm{NaCl} ; 0.03 \mathrm{M}$ sodium citrate) at $45^{\circ} \mathrm{C}$ and twice with PN buffer $(0.05 \%$ Nonidet P-40 in PBS, pH 8.0) at $30^{\circ} \mathrm{C}$. This was followed by incubation with mouse anti-BrdU antibodies (Sigma Chem.Co., MO, US) diluted to 1:200 in PBS for $30 \mathrm{~min}$ at $37^{\circ} \mathrm{C}$, and incubated with FITC conjugate secondary goat antibodies (Sigma) diluted to 1:100. Preparations were observed under UV (Ansari et al. 1993). Poliovirus-infected HEp-2 cell cultures were used as Tunel positive control.

\section{RESULTS}

Rotavirus-infected cell viability assayed by TB exclusion staining is shown in Fig. 1, at indicated period of time. The percentage of cell viability varied from $10.1 \%$ at time zero to $21.5 \%$ at $12 \mathrm{~h}$ p.i. for porcine strain. For simian strain it varied from $10 \%$ at time zero to $18 \%$ at $12 \mathrm{~h} \mathrm{p.i.}$

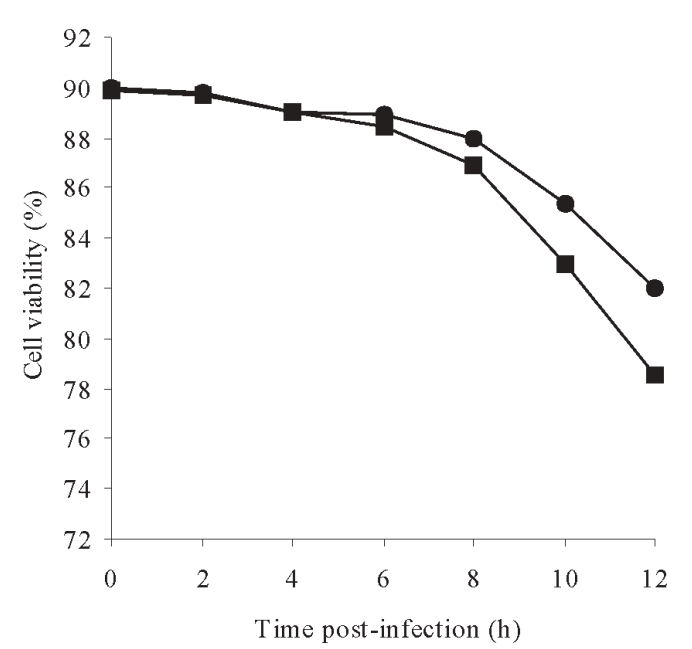

Fig. 1: percentage of cell viability in rotavirus-infected MA-104 cell cultures. Simian $(\bullet)$ and porcine $(\square)$ strain-infected cell cultures at a multiplicity of infection of approximately 1 at the indicated time intervals. 
Infected cells submitted to CR test, at the same time intervals, demonstrated that for simian strain percentages of chromium release from $2 \%$ at time zero to $24 \%$ at $12 \mathrm{~h}$ p.i. were observed, and for porcine strain $4 \%$ at time zero to $27.5 \%$ at $12 \mathrm{~h}$ p.i. (Fig. 2). Concerning nuclear fragmentation monitored by $\mathrm{AO}$ and Wright staining no difference was detected among infected and control cells 24 h p.i.,

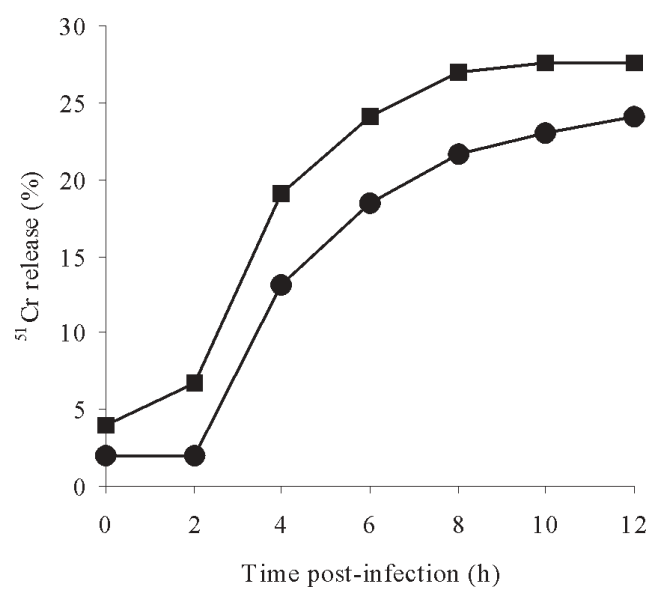

Fig. 2: percentage of chromium $\left({ }^{51} \mathrm{Cr}\right)$ release in rotavirus-infected MA-104 cell cultures. Simian $(\bullet)$ and porcine (Ш) strain-infected cell cultures at a multiplicity of infection of approximately 1 at the indicated time intervals. for both strains. However, at $48 \mathrm{~h}$ p.i. fragmentation was observed in approximately 2 and $4 \%$ of infected cells, respectively for simian and porcine strains (Fig. 3).

Thin sections of porcine virus-infected cell cultures, harvested at $12 \mathrm{~h}$ p.i., revealed a decrease in the ratio of cellular and nuclear volumes. Condensation and marginalization of the chromatin, increase of the nucleoli, and vacuolisation of the cytoplasm were also observed. Loss of intercellular contacts was demonstrated (Fig. 4A). Enveloped and non-enveloped virus particles were also detected within dilated cistern (Fig. 4A, B). Similar results were also found in simian virus-infected cells (not shown).

DNA of infected cultures, collected at 8, 24, 48, and 96 h p.i., extracted and submitted to AGE and PAGE showed no cleavage as to form fragments of 180-200 pb. However, it was demonstrated that from $24 \mathrm{~h}$ p.i. onward virus yields increased significantly as shown by the optical density of viral RNA segments in AGE (not shown). Tunel technique revealed negative results for both strains (not shown).

\section{DISCUSSION}

Rotavirus infection in vitro and in vivo is associated to several sub-cellular pathological changes that ultimately culminate with cell lysis. The mechanism that rotaviruses use to interact with host cell and results in cytopathytic effect is not clearly defined. It is thought that these

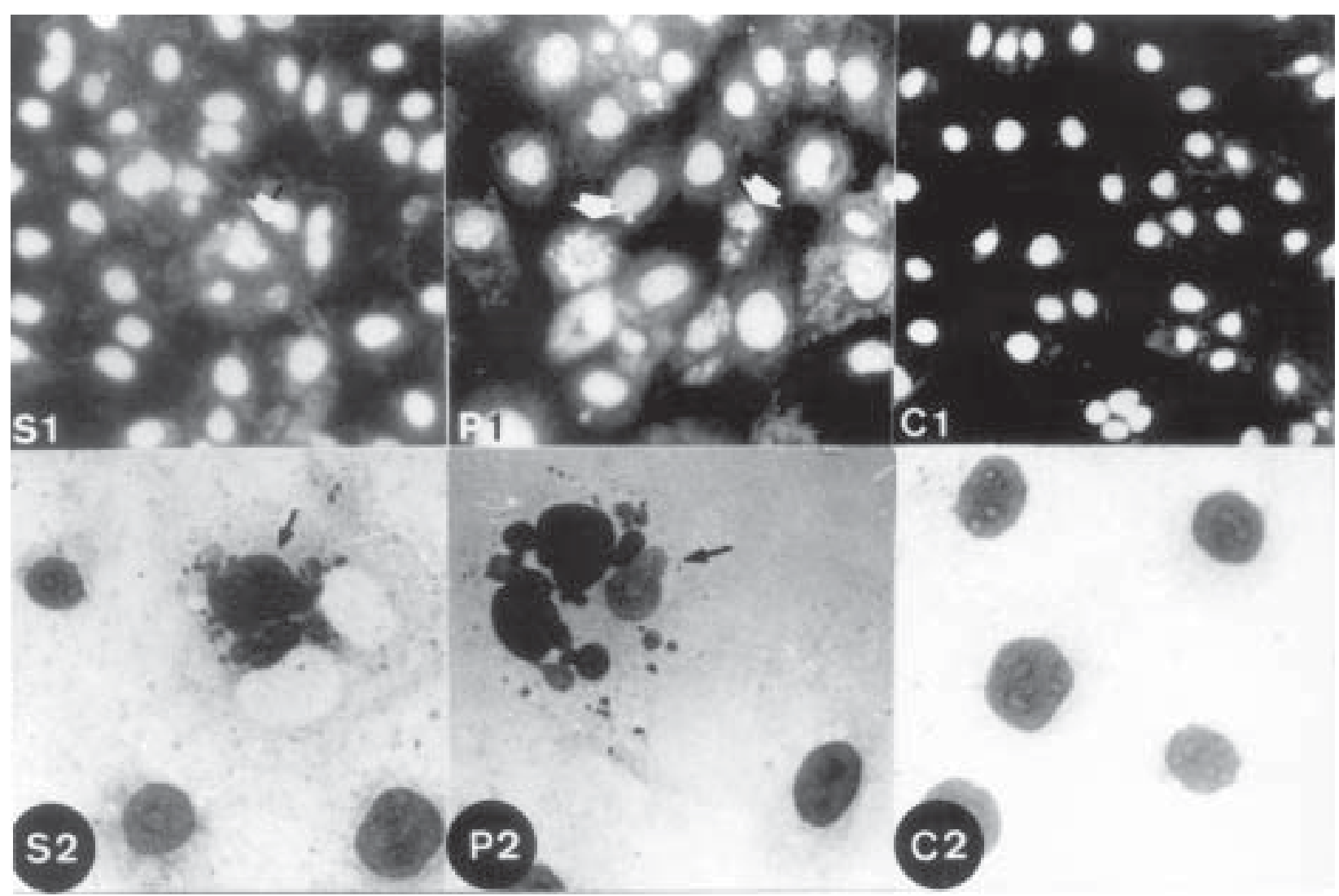

Fig. 3: nuclear fragmentation in simian (S) and porcine (P) rotavirus-infected MA-104 cell cultures. Cell cultures infected at a multiplicity of infection of approximately 1, $48 \mathrm{~h}$ p.i. stained with acridine orange (AO) (S1 and P1, 200X) and Wright stain (W) (S2 and P2, 400X) showing nuclear fragmentation (arrow). Control non-infected cell cultures stained with AO (C1, 200X) and W (C2, 400X). 


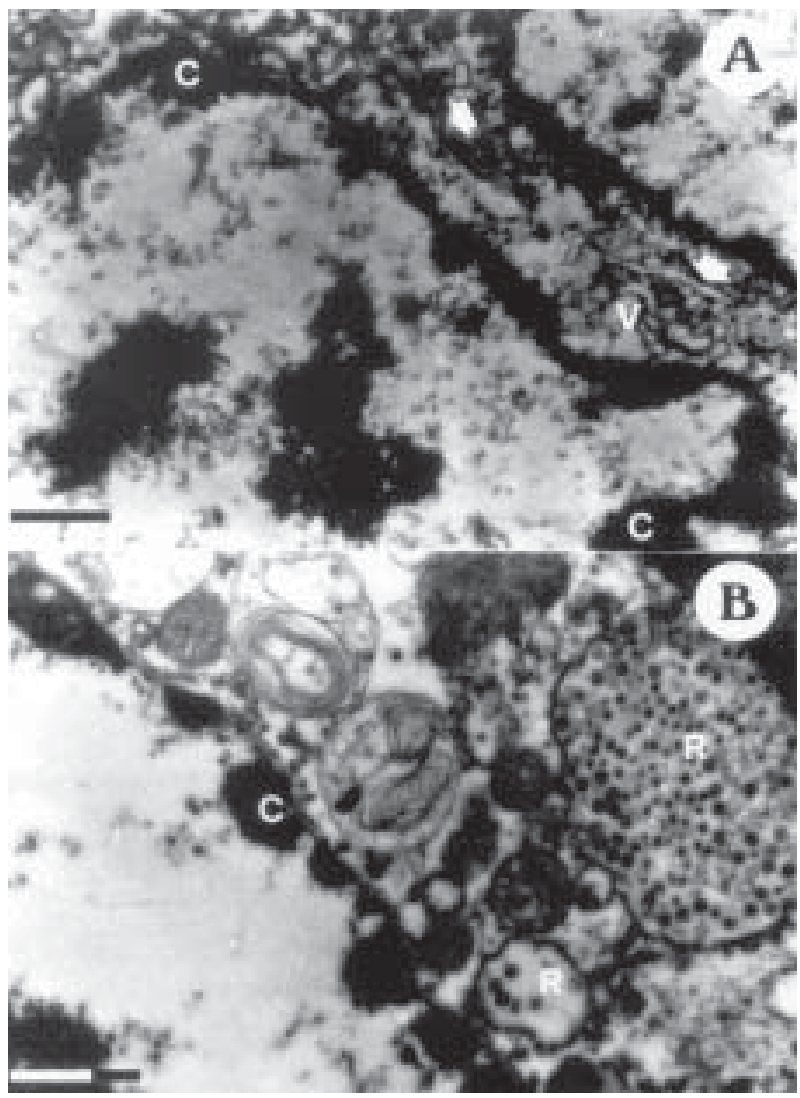

Fig. 4: ultra-thin sections of porcine rotavirus-infected MA-104 cell cultures, $12 \mathrm{~h}$ p.i. A: perinuclear condensation of chromatin (C), vacuolisation of the cytoplasm (V), loss of intercellular contact (arrow). Bar $1.2 \mu \mathrm{m}$; B: perinuclear condensation of chromatin (C), and enveloped and non-enveloped virus particles within dilated cisternae (R). Bar $1.2 \mu \mathrm{m}$

changes may represent a key role in the pathogenesis of diarrhoeic disease caused by rotaviruses.

In the current work, the analysis of cell viability after infection with simian and porcine strains of rotavirus demonstrated that in the absence of cellular morphological changes, respectively, 18 to $22 \%$ of the cells presented altered membrane permeability $12 \mathrm{~h}$ p.i., as shown by TB uptake. CR assayed at the same time intervals demonstrated that over 23 and $27 \%$ of the radioactivity were released, respectively, for simian and porcine strains by $12 \mathrm{~h}$ p.i. Death of rotavirus-infected cells has been established as being caused by lytic process (Estes 1996). However, it was suggested that some cytopathic events observed in rotavirus-infected cells, including chromatin clumping could be attributed to apoptosis induced by the virus (Superti et al. 1996). In our experiments necrosis takes place as shown by membrane permeability derangement. Also infected cells presented nuclear fragmentation later in infection, observed after WS and AO staining. We suggested that death of rotavirus-infected cells occur mainly due to necrosis, at least for the virus strains we used. However, a small percentage of infected cells showed evidence of apoptosis as demonstrated by the nuclear fragmentation, although Superti et al. (1996) suggested that apoptosis was the prevalent process in the cytopathology of rotavirus. Nuclear fragmentation was demonstrated in our experiments but we could not detect DNA ladder internucleosomal fragments, as shown by Pérez et al. (1998) with OSU strain of porcine rotavirus, but this may not be mandatory in rotavirus-induced apoptosis (Superti et al. 1996). Cohen et al. (1992) and Oberhammer et al. (1993) showed apoptotic ultrastructural changes in the absence of internucleosomal cleavage. As far as ultrastructural changes are concerned we detected some changes that could be attributed to apoptosis in infected cells in comparison to controls. High molecular weight DNA fragments (300-700 bp and $50 \mathrm{Kbp}$ ) were described to occur previously to internucleosomal cleavage (Brown et al. 1993, Zhivotovsky et al. 1994) suggested as an irreversible signal of apoptosis (Orrenius 1995). Yet again our results did not demonstrate high molecular weight DNA fragments either.

Although histochemical staining have shown nuclear fragmentation we could not demonstrate Tunel positive reaction. It is possible that either AGE and PAGE are not enough sensitive to detect low scale DNA fragmentation or alternatively there could be different endonucleases involved, not allowing Tunel reaction (Desjardins \& MacManus 1995). These findings may suggest that overall lytic alterations observed in rotavirus-infected cells should be attributed to cytotoxic origin. This may be explained by the accumulation of viral proteins as suggested by Michelangeli et al. (1995) and loss of cytoplasmic membrane integrity even early in infection, as we showed by TB uptake and CR. In corroboration, NSP4 increases cytoplasmic membrane permeability being, therefore, implicated in rotavirus cytophatic effect due to changes of $\mathrm{Ca}^{2+}$ permeability in the endoplasmic reticulum (ER) (Newton et al. 1997). This type of trans-ER resident glycoprotein has been suggested to act, among other functions, as diarrhoea inducing enterotoxin in mice and in the reorganisation of cellular $\mathrm{Ca}^{2+}$ (Ball et al. 1996, Newton et al. 1997, Mirazimi et al. 1998). In fact, Exton (1994) demonstrated that the increase of intracellular $\mathrm{Ca}^{2+}$ in response to NSP4 could alter cell metabolism in activating enzymes and ultimately leading to necrosis.

In conclusion, we suggested that both species of rotavirus studied interact with cultured cells overall as a lytic process and necrosis seems to be the basis of their cytopathology.

\section{REFERENCES}

Alonso C, Oviedo JM, Martin-Alonso JM, Díaz E, Boga JA, Parra F 1998. Programmed cell death in the pathogenesis of rabbit hemorrhagic disease. Arch Virol 143: 321-332.

Ansari B, Coates PJ, Greenstein BD, Hall PA 1993. In situ endlabelling detects DNA strand breaks in apoptosis and other physiological and pathological states. J Pathol 170: 1-8.

Ball JM, Tian P, Zeng CQ, Morris AP, Estes MK 1996. Agedependent diarrhoea induced by a rotaviral nonstructural glycoprotein. Science 272: 101-104.

Blacklow NR, Greenberg HB 1991. Viral gastroenterites. N Engl J Med 325: 252-264.

Brown DG, Sun XM, Cohen GM 1993. Dexamethasone-in- 
duced apoptosis involves cleavage of DNA to large fragments prior to internucleosomal fragmentation. $\mathrm{J}$ Biol Chem 268: 3037-3039.

Cohen GM, Sun XM, Snowden RT, Dinsdale D, Skilleter DN 1992. Key morphological features of apoptosis may occur in the absence of internucleosomal DNA fragmentation. Biochem J 286: 331-334.

Derfuss T, Fickenscher H, Kraft MS, Henming G, Lengenfelder D, Flekenstein B, Meine E 1998. Antiapoptotic activity of the herpesvirus saimiri-encoded Bcl-2 homology: stabilization of mitochondria and inhibition of caspases-3-like activity. J Virol 72: 5897-5904.

Desjardins LM, MacManus J P 1995. An adherent cell model to study different stages of apoptosis. Exp Cell Res 216: 380-387.

Estes MK 1996. Rotaviruses and their replication. In BN Fields, DM Knipe, PM Howley, RM Chanock, MS Hirsch, JL Melnick, TP Monath (eds), Virology, 3rd ed., Vol. 2, Lippincott-Raven Publishers, Philadelphia, p. 1625-1655.

Exton JH 1994. Phosphatidylcholine breakdown and signal transduction. Biochim Biophys Acta 1212: 26-42.

Guimarães MAAM, Nozawa CM 1990. Acridine orange metachromasia in the cytoplasm of simian rotavirus (SA11)-infected MA-104 cell cultures. Braz J Med Biol Res 23: 169-177.

Herring AJ, Inglis NF, Ojeh CK, Snodgrass DR, Menzies JD 1982. Rapid diagnosis of rotavirus infection by direct detection of viral nucleic acid in silver-stained polyacrylamide gel. J Clin Microbiol 16: 473-477.

Kapikian AZ, Chanock RM 1996. Rotaviruses. In BN Fields, DM Knipe, PM Howley, RM Chanock, MS Hirsch, JL Melnick, TP Monath (eds), Virology, 3rd ed., Vol. 2, Lippincott-Raven Publishers, Philadelphia, p. 1657-1708.

Lundgren O, Svensson L 2001. Pathogenesis of rotavirus diarrhea. (Review). Microbes and Infection 3: 1145-1156.

Majno G, Joris I 1995. Apoptosis, oncosis, and necrosis. An overview of cell death. Am J Pathol 146: 3-15.

McDonell MW, Simon MN, Studier FW 1977. Analysis of restriction fragments of T7 DNA and determination of molecular weights by electrophoresis in neutral and alkaline gels. J Mol Biol 110: 119.

Mirazimi A, Nilsson M, Svensson L 1998. The molecular chaperone calnexin interacts with the NSP4 enterotoxin of rotavirus in vivo and in vitro. J Virol 72: 8705-8709.

Michelangeli F, Liprandi F, Chemello MH, Ciarlet M, Ruiz MC 1995. Selective depletion of stored calcium by thapsigargin blocks rotavirus maturation but not the cytopathic effect. J Virol 69: 3838-3847.

Newton K, Meyer JC, Bellamy AR, Taylor JA 1997. Rotavirus nonstructural glycoprotein NSP4 alters plasma membrane permeability in mammalian cells. J Virol 71: 9458-9465.

Oberhammer F, Wilson JW, Dive C, Morris ID, Hickman JA, Wakeling AE, Walker PR, Sikorska M 1993. Apoptotic death in epithelial cells: cleavage of DNA to $300 \mathrm{bp}$ and/or $50 \mathrm{Kbp}$ fragments prior to or in the absence of internucleosomal fragmentation. Embo J 12: 3679-3684.

Orrenius S 1995. Apoptosis: molecular mechanisms and implications for human disease. J Inter Med 237: 529-536.

Oura CAL, Powell PP, Parkhouse RME 1998. African swine fever: a disease characterized by apoptosis. J Gen Virol 79: 1427-1438.

Patton JT 1995. Structure and function of the rotavirus RNA binding proteins. J Gen Virol 76: 2633-2644.

Pérez JF, Chemello ME, Liprandi F, Ruiz MC, Michelangeli F 1998. Oncosis in MA 104 cells is induced by rotavirus infection through an increase in intracellular $\mathrm{Ca}^{2+}$ concentration. Virology 252: 17-27.

Polos PG, Gallaher WR 1981. A quantitative assay for cytolysis induced by Newcastle disease virus. J Gen Virol 52: 259-265.

Ramos APD, Stefanelli CC, Linhares REC, Brito BG, Santos NS, Gouvea V, Lima RC, Nozawa CM 2000. The stability of porcine rotavirus in feces. Vet Microbiol 71: 1-8.

Shaw RD, Hempson SI, Mackow ER 1995. Rotavirus diarrhoea is caused by nonreplicating viral particles. J Virol 69: 5946-5950.

Superti F, Ammendolia MG, Tinari A, Bucci B, Giammarioli AM, Rainaldi G, Rivabene R, Donelli G 1996. Induction of apoptosis in HT-29 cells infected with SA-11 rotavirus. $J$ Med Virol 50: 325-334.

Teodoro GV, Branton EP 1997. Regulation of apoptosis by viral genes products. J Virol 71: 1739-1746.

Tolskaya EA, Romanova LI, Kolesnikova MS, Ivannikova TA, Smirnova EA, Raikhlin NT, Agol VI 1995. Apoptosis-inducing and apoptosis-preventing function of poliovirus. J Virol 69: 1181-1189.

Uehara T, Miyawaki T, Ohta K, Tamaru Y, Yokoi T, Nakamura S, Taniguchi N 1992. Apoptotic cell death of primed $\mathrm{CD}^{2} 5 \mathrm{RO}^{+} \mathrm{T}$ lymphocytes in Epstein-Barr virus-induced infectious mononucleosis. Blood 80: 452-458.

Wyllie AH, Morris RG, Smith AL, Dunlop D 1984. Chromatin cleavage in apoptosis: association with condensed chromatin morphology and dependence on macromolecular synthesis. J Pathol 142: 67-77.

Zhivotovsky B, Wade D, Gahm A, Orrenius S, Nicotera P 1994. Formation of $50 \mathrm{Kbp}$ chromatin fragments in isolated liver nuclei is mediated by protease and endonuclease activation. FEBS Letters 351: 150-154. 